\title{
Marketing through the Coronavirus Crisis - How Marketers in Albania Deal with the Ongoing Crisis of Covid-19
}

\author{
Ana Buhaljoti
}

\section{Abstract}

None of the 21st century economic hardships have posed such a significant threat on businesses as the global pandemic COVID-19. In Albania beyond the evident threat it is causing to the human well-being, the coronavirus is threatening the health of businesses. According to the Albanian Institute of Statistics, in the second quarter of 2020, GDP in volume terms has decreased by $10.2 \%$ compared with the second quarter of 2019 . This crisis gives a reflection to how the businesses in Albania do marketing and manage marketing risk. The purpose of this paper is therefore to investigate the Albanian marketers point of view and actions within the ongoing crisis caused by covid-19. The study aims to understand how marketers are dealing with the situation right now and whether they are taking a proactive or reactive approach. There is no current evidence whether marketers are managing crisis with a reactive method, purely tactical or proactively with a strategic viewpoint. In line with the purpose of this study a qualitative research approach was taken to gain insights on marketing through the coronavirus crisis in Albania. The depth interviews conducted with marketing managers of four different industries collected rich information on handling the coronavirus crisis and concluded that marketers were unprepared and adopted a reactive approach when dealing with the covid-19 crisis. Further the Covid-19 crisis gave rise to a more attentive and sensitive tone towards digital marketing in strengthening relationships with both partners and consumers.

Keywords: marketing, crisis management, Covid-19, Albania

JEL Classification: according to the JEL Classification System

\section{Introduction}

None of the 21st century economic hardships have posed such a significant threat on businesses as the global pandemic COVID-19. In Albania beyond the threat it is causing to the human well-being, the coronavirus is threatening the health of Albanian businesses. According to the Albanian Institute of Statistics, in the second 
quarter of 2020, GDP in volume terms has decreased by $10.2 \%$ compared with the second quarter of 2019. (OECD 2020)

The impact on the overall economy is severe, with large falls in tax revenue, increases in debt and loss of employment. Based on World Bank firms are suffering from reduced demand, reduced labor supply and from constraints to sourcing material inputs. $61 \%$ of firms remain profitable and almost all firms in the highly impacted sectors register losses. (World Bank 2020)

This crisis gave reflection to how the businesses in Albania are managing the situation and what implications it has for marketing. Although previous studies on marketing in times of economic crisis indicate to invest in marketing, in reality most companies in Albania are doing the opposite and are cutting their marketing funds. Marketing budgets are cut because of top managers' short-term focus and the changing behavior of customers. According to O'Malley et al., 2011, during a crisis consumer become more value-oriented, tend to have a consumption-discouraging lifestyle and trust less in businesses and the economy. (O'Malley et al., 2011) Consequently, marketers become more worried about cash and tend to cut off costs by reducing the support to brands together with reducing market research efforts. They also switch from traditional marketing to online marketing in order to reduce costs. (Nickell et al., 2013)

Whether coronavirus with its rapid spread has caused marketers to take a proactive or reactive approach has to be further investigated in this study. The aim is to understand how marketers are dealing with the situation and what are their actions and expectations for the future. In line with the purpose of this study a qualitative research approach was taken to gain insights on marketing through the coronavirus crisis in Albania.

\section{Literature Review}

Most of the studies on crisis are related to the management discipline analyzing crisis as a component in business planning and activating alternative plans in response to a critical situation. Although it naturally overlaps other fields, the number of studies that are related to how marketing should be conducted during a crisis are very few and studies that are specifically related to marketing during pandemics are rarer. (Jaques, 2007)

The review by Bundy et al. (2017) testifies a lack of integration across fields and limited consensus about crisis management. From a business perspective, crisis is the perception of an emergent event that threatens stakeholders' expectations regarding safety and economic matters and can damage an organization's performance. (Coombs 2019) Previous research on crisis has focused on developing frameworks for managing crisis and diminishing the impact of a potential crisis. By major authors crisis management is seen as more of a reactive activity as action is decided upon 
problems are escalating. (Coombs 2019, Bundy et al. 2017, Seeger et al., 2003 , Jaques, 2007)

Meanwhile previous studies on marketing in times of economic crisis testify a limited effort among businesses in regard to pre preparing for crises. How marketers approach a crisis often is reactive by cutting marketing expenditures and investments. Authors indicate that marketers tend to disregard strategic considerations and focus on situational circumstances. Marketing budgets are cut as a consequence of top managers' short-term focus and a lack of market orientation. (Quelch et al. 2009, O'Malley et al., 2011)

Nickell et al., 2013 investigated how marketers acted during the Great Recession and found that they decreased marketing spending and company's investments. Highperforming companies strengthened strategic customer accounts and invested in customer relationships. The crisis became a catalysator for the shift from traditional marketing to online marketing (Nickell et al, 2013).

When entering a recession, marketers' success depends on their ability to adapt quickly to the new situation. Research argues for a critical need to re-strategise to adapt to a "new normal". (Piercy et al. 2010).

Jaques (2007) views crisis management with a strategic viewpoint. It includes proactive process that are interrelated such as prevention, preparation, response, and recovery. These phases are set by Pearson and Mitroff Model in Figure 1. (Jaques 2007, Pearson and Mitroff 1993)

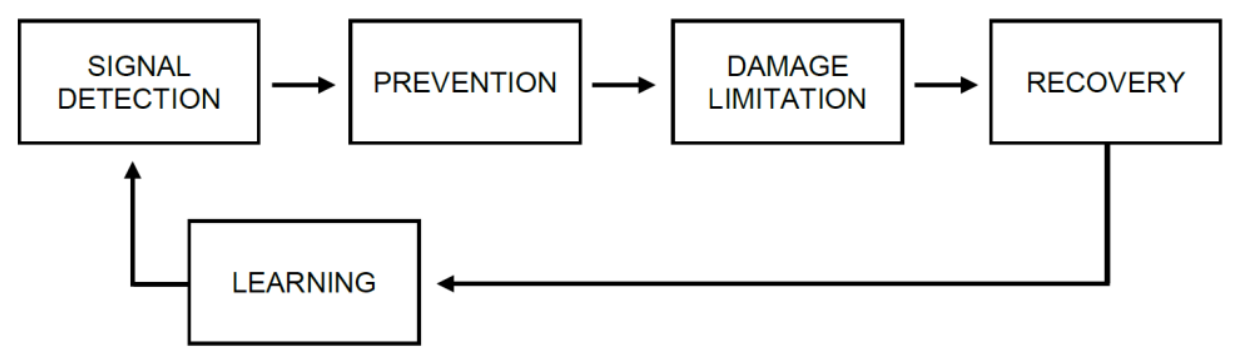

Fig.1 Model of Crisis Management (Pearson and Mitroff 1993)

The signal detection or recognition of a crisis earlier is crucial for minimizing the threat to the organization. Signal detection is difficult in crises of the sudden type, such as a pandemic crisis due to its unexpected nature. James and Wooten (2005) state that warning signals often are ignored, or even worse blocked by organizations, as they are hit by storm of information. Organizations shall continuously scan for potential problems before they escalate and grow into a crisis. (Pearson \& Mitroff 1993)

Prevention is "a rational way to select which potential problems an organization should prepare for and which can be 'safely' ignored". (Pearson \& Mitroff 1993) 
Organizations can group crises of similar nature together in different categories. Thus, creating a portfolio of crises which will help determine the threat level and design a suitable strategy to approach at least in each crisis category. The goal of crisis management is not to prevent every possible crisis from happening, but to effectively prepare and manage the ones that cannot be prevented.

The organization shall prepare effective mechanisms and activities to limit damage. According to Pearson \& Mitroff, 1993 it shall prepare an effective crisis management system over five different factors: (a) technical, (b) human, (c) infrastructural, (d) cultural, and (e) emotional (Pearson \& Mitroff, 1993). Organizations must consider damage from the context of its environment and not turn their back to stakeholders in order to limit damage and protect their own interests.

This reasoning implies a proactive approach to crisis management. Crisis-prepared organizations have both short-term and long-term business recovery programs. (Pearson \& Mitroff, 1993)

Recovery requires communicating correctly with stakeholders to reassure that the disruption caused is not affecting the operations. Organizations can approach a crisis as an opportunity to create a better organization by adopting a learning mentality (James \& Wooten, 2005). Those that spend time to analyze and learn from past crises can use that insight into the crisis management processes in order to be better prepared for potential future crises. Some authors have connected organizational learning to the concept of resilience. (McCarthy et al., 2017; Williams et al., 2017) Resilience refers to anticipating and adjusting to secular trends that can permanently impair the earning power of a business (Weick and Sutcliffe 2007). According to Boin and van Eeten (2013) resilience is a solution to the challenging circumstances created by a crisis and depends on the organization ability to absorb the shock and bounce back after a crisis impact. (Boin and van Eeten 2013) Planning for unexpected risks sets organization's up for responding incorrectly using old solutions for new problems that are different to past situations. Instead organizations should learn to deal with adversity reactively by maintaining high-level performance despite the presence of environmental pressure. Weick and Sutcliffe (2007) further state that unexpected events often assess resilience by affecting how much an organization stretch without breaking and then how well it recovers. (Weick and Sutcliffe 2007)

Kotler and Caslione (2009) argue that resilience is crucial for marketing success in times of crisis. The marketer is required to gain the attention and engagement of the marketplace through the turbulence of the crisis. Key ingredients for success are an understanding of how the needs of stakeholders change by working closely with key clients, analysing the challenges that the dramatic downturn posed to them and finding innovative solutions to this new situation. (Kotler and Caslione 2009, Nickell, et al., 2013). This is crucial as sales largely depend on consumers' having sufficiently disposable incomes, positive outlooks on the future, trust in businesses and the economy. (Quelch \& Jocz, 2009) 
Thus, instead of responding tactically to the situation, by experimenting with digital marketing, Jaques (2007) encourages a strategic viewpoint that includes interrelated processes, such as prevention, preparation, response, and recovery in order to manage and nurture relationships with current stakeholders on the premises of relationship marketing.

\section{Methodology}

The purpose of this paper is to investigate how marketers are reasoning and acting in the ongoing crisis caused by Covid-19. In line with this purpose a qualitative research approach was taken to explore marketer's perception through the coronavirus crisis in Albania. The qualitative research is the most adequate method to study the phenomena in their natural settings with the meanings that people connect to it. The emphasis is on "the socially constructed nature of reality" (Denzin \& Lincoln, 2005). The data collection method is in-depth interviews to ensure a rich data collection in a social context. Four semi-structured interviews were conducted with marketing professionals in Albania to collected rich information on their experiences in handling the covid-19 crisis. Marketing managers were interviewed in the middle of the crisis to get a more truthful view of how marketing should be conducted during a crisis.

To ensure confidentiality, only the industries of the interviewed marketing professionals are mentioned, instead of the names. A summary of the respondents in each industry is shown in Table 1

Table 1 Company industry and respondents per industry

\begin{tabular}{|l|l|}
\hline Company Industry & Respondents \\
\hline Telecommunication & Respondent 1 \\
\hline Retail & Respondent 2 \\
\hline E-commerce & Respondent 3 \\
\hline $\begin{array}{l}\text { Coffee } \\
\text { Manufacturing }\end{array}$ & Respondent 4 \\
\hline
\end{tabular}

\section{Empirical findings}

All interviewed Albanian marketers shared that Covid-19 pandemic crisis came as a complete surprise and none of them had expected it. When asked about initial reactions, all respondents stated that they saw the crisis very distant in the early stages (January and February) as it could not affect them. The respondents continued describing how their attitude completely changed from the 10th of March, when the Albanian society shut down. At that point they began to mentally prepare for losing sales, take step back with marketing and put marketing expenditures on hold.

Respondent 2 expressed its initial feelings as: "I always think that things will eventually settle. Its just a virus, it can't be a big deal." 
Respondent 4 expressed its initial feelings as: "I could not see how this would come to affect us."

When asked about how prepared the agencies were for a potential crisis of any kind, the interviewees agreed that no one was prepared for a pandemic, neither had plans for economic downturns. All respondents agreed that they do not have a crisis plan as it is not necessary, but being reactive and adaptable is crucial for any downturn.

Respondent 1 stated that "Having a sufficient budget keeps us from falling under the pressure of a crisis" Further as a large company representative the marketer stated that "we tend to prepare for crises in times of accidents and associate it to something terrible happening at the company, such as a media scandal."

Respondent 3 pointed out that they have a wide customer base and are not stuck in one industry. "We reacted immediately by diversifying our product portfolio, considering the new products demanded as customers were spending more time at home"

A change in consumer behavior was also noted by respondents 2 and 3, where consumption has moved to home-activities such as baking and furnishing, providing implications of the industries that are benefitting from the crisis, corresponding to the industries of respondents 1 and 2 .

Respondent 2 stated that: "you cannot prepare yourself so much, but it's more about being quick to think and make decisions about the next measure to take in the worst scenario."

All interviewee agreed that it was unlikely that any company could have prepared themselves for a crisis as the current one, as it was very unexpected.

In terms of prevention measures, marketers were asked about prior analysis of the situation to prepare for crisis.

Respondent 1 and Respondent 2 replied that their company conducts environmental analyses and risk analyses, respondent 3 said they conduct situational analyses while respondent $\mathbf{4}$ said they did not have any situational analysis oh hand immediately.

Respondent 1 explained that both environmental analyses and risk analyses allow them to form strategies and go through target groups and risk strategies: "we tend to built scenarios around worst case, around sales, like how fast downwards can it go now"

When asked about the damage caused so far by the pandemic crisis respondent 1 and respondent 2 meant that there are regional differences within the industry, in terms of the influence of the pandemic. Respondent 4 brought up the profitability issue of the industry as a factor they believe is aggravating. "The fear for one's health and of being in a public space with a surrounding crowd has heavily impacted the coffee retailers. Consumers' fear is changing consumer behavior in bars" said Respondent 4. 
The participants further said that layoffs were a preventive measure taken to be prepared for the coming months. The numbers of hours for workers have been lowered per week until we see how the situation is looking ahead.

Respondent 2 said that "employees were asked to take out their saved vacation days from the previous period, in order to make sure that none of the workers are gone on long vacation once things start to speed up again".

As for the strategies to mitigate the impact of the crisis respondents 2 and $\mathbf{3}$ claimed adaptability to be the main strategy.

"We have adapted to the current situation. We are developing daily, so this is a development into another direction."

Respondent 3 explained that their strength has been their digital expertise in regard to visibility to potential clients who switched from traditional commerce to ecommerce. "It was a good time to work on branding and strengthening the relationships with our clients and suppliers".

When asked about the opportunities of this crisis and what could be learned from it, the responses varied.

Respondent 1 and 2 believed that the situation has given firms an incentive to prepare for future crises better by increasing their savings and financial buffers. Respondent 3 thought firms have to aim for a more careful growth strategy and more stable and secure operations, rather than focusing on "quick" and "short-term". Respondent 1 expressed the importance of communication both internally and externally with stakeholders in order to handle the situation well.

Respondent 2 and 3 recognized that better digital knowledge and skills with technology are required as companies that digitalized marketing operations using technology are now in competitive advantage.

Respondent 3 stated that "E-commerce is an area that companies failed to see before and each has to exploit the digital potential further" Respondent 2 stated that "the digitization process is difficult, but in this situation, we had to do it overnight, no one could question it anymore."

Respondent 1 and 2 considered strengthening online shopping and web shops as more is done digitally now.

Respondent 4 stated that "everyone is online now, students in university are conducting online studies, public sector workers hold meetings online. online is becoming more normal"

All respondents shared the idea that the current situation is a good time for selfimprovement in terms of digital marketing. Respondent 3 stated: 
"among marketing managers, there are many who understand digital marketing and many who do not. This is an opportunity to further develop the skills necessary for the digitalization process as the current marketing trend"

Digital marketing is seen as a winner in this pandemic by all marketers of different industries. Marketers agreed that the crisis served as a catalysator for further digitalization.

The interviewees were at last asked to describe things they could have done better.

Respondent 4 noted that it is impossible to predict for future crises.

Respondent 1 stated that "better knowledge and skills with technology would have been beneficial".

Both Respondent 1 and 2 were forced to progress in e-commerce quickly and they could have taken more advantage of the technology. However, they feel more comfortable with using technology for managing daily business operations now than ever before.

All the marketing managers interviewed had learnt from this crisis that there are functions of marketing where they need help that they have not considered before. They are all open to digitalizing their marketing efforts, as well as certain parts of their operations.

Respondent 2 stated that "our business partners came to realize the importance of communication as well as the power of using digital tools and social media to accomplish it.

Respondent 3 further expressed that the crisis has acted as a catalyst for new ways of working such as video meetings are a new standard at work together with online interaction with customers.

The crisis has accelerated a digitalization process on the Albanian marketplace, which seem to have been on hold among the marketing departments of the Albanian businesses. All respondents agreed that they learnt from this experience and use it in preparation for the future, as there is room for improvement towards modern marketing methods.

\section{Conclusion}

The purpose of the study has been to answer the research question how marketers are reasoning and acting in the ongoing crisis caused by Covid-19 and whether they are taking a proactive or reactive approach.

Professionals of marketing in four different Albanian industries were interviewed in the middle of the crisis to get a more truthful view of how marketing should be conducted during a crisis. 
After the collection of data, a thematic analysis was conducted to highlight certain themes. The findings give indications of Albanian marketers and consumers' reactions to the covid-19 pandemic crisis. The findings show that the marketers were unprepared for a crisis. None of the marketing representatives of the four selected industries had crisis plans prepared for any crisis at all. As the crisis arose, they were faced with the decision of whether to neglect the changing environment and continue as usual or re-strategize. None of the marketing professionals had considered a crisis scenario before, but after detecting the signals and realizing the reality of the crisis had returned to action planning. All the represented industries resorted to a reactive strategy for handling the situation. The participants generally agreed that it would have been difficult for any company to anticipate covid-19 pandemic.

The financial situation is what has had put companies under the pressure of the crisis, and therefore, the marketers speculated that building an emergency fund would be an option for the future. Also, effective internal communication has been important during the crisis, in order to turn fear into an opportunity for improvement.

Marketers enhanced that the crisis was a catalysator for further digitalization. The crisis has thus accelerated a digitalization process on the Albanian marketplace, which is something that has been long awaited among the Albanian marketers interviewed. Digital marketing is not a complement marketing strategy anymore, it is the core marketing strategy. Overall marketers showed their willingness to learn from the experience, as an opportunity to further develop the skills necessary for the digitalization process as the current marketing trend in Albania.

To sum up the findings, marketers need to rethink their strategies as the needs and behavior of their customers change. Marketing in times of crisis is seen by Albanian marketers as reactive only and marketing management is purely tactical. Marketers need to take a more proactive approach by being attentive in nurturing relations with clients as a competitive asset especially in a crisis situation.

\section{References}

[1] Boin, A., \& van Eeten, M. (2013). The Resilient Organization. Public Management Review: Disaster and Crisis Management, 15(3), 429-445. https://doi.org/10.1080/14719037.2013.76985

[2] Bundy, J., Pfarrer, M. D., Short, C. E. and Coombs, W. T. (2017). Crises and Crisis Management: Integration, Interpretation, and Research Development. Journal of Management. 43(6), 1661-1692

[3] Coombs, W. T. (2019). Ongoing crisis communication: planning, managing, and responding. 5th Edition. Los Angeles: SAGE.

[4] Denzin, N. K. \& Lincoln, Y. S. (2005). The SAGE Handbook of Qualitative Research. Thousand Oaks, California: SAGE Publications 3rd ed.

[5] International Monetary Fund (2020), World Economic Outlook (Washington, D.C., 
[6] https://www.imf.org/external/datamapper/NGDP_RPCH@WEO/OEMDC/A DVEC/WEOWORLD?year $=2020$

[7] James, E., \& Wooten, L. (2005). Leadership as (un)usual: how to display competence in times of crisis. Organizational Dynamics, 34(2), 141-152. https://doi.org/10.1016/j.orgdyn.2005.03.005

[8] Jaques, T. (2007). Issue management and crisis management: An integrated, non-linear, relational construct. Public Relations Review, 33(2), 147-157. https://doi.org/10.1016/j.pubrev.2007.02.001

[9] Kotler, P. \& Caslione, J. (2009). How marketers can respond to recession and turbulence. Journal of Customer Behaviour, 8(2), 187-191. https://doi.org/10.1362/147539209X459804

[10] Ki, E.J. and Nekmat, E. 2014. Situational crisis communication and interactivity: Usage and effectiveness of Facebook for crisis management by Fortune 500 companies. Computers in Human Behaviour 35, pp. 140-147

[11] Lohiniva, A. L.; Sane, J.; Sibenberg, K.; Puumalainen, T. and Salminen, M. 2020. Understanding coronavirus disease (COVID-19) risk perceptions among the public to 69 enhance risk communication efforts: a practical approach for outbreaks. Euro Surveillance 25 (13), pp. 1-4.

[12] Murty, A. V. N. and Subramanian, K. S. L. N. S. 2014. The role of communication in crisis management (an organisational perspective) International Journal of Human Resource Management and Research 4 (5), pp. 33-44.

[13] McCarthy, I., Collard, M., \& Johnson, M. (2017). Adaptive organizational resilience: an evolutionary perspective. Current Opinion in Environmental Sustainability, 28, 33-40. https://doi.org/10.1016/j.cosust.2017.07.005

[14] Nickell, D., Rollins, M., \& Hellman, K. (2013). How to not only survive but thrive during recession: a multi-wave, discovery-oriented study. Journal of Business \& Industrial Marketing, 28(5), 455-461. https://doi.org/10.1108/08858621311330290

[15] OECD (2020), Covid-19 crisis in Albania, http://www.oecd.org/south-easteurope/COVID-19-Crisis-in-Albania-archive.pdf

[16] O'Malley, L., Story, V., \& O'Sullivan, V. (2011). Marketing in a recession: retrench or invest? Journal of Strategic Marketing, 19(3), 285-310. https://doi.org/10.1080/0965254X.2011.581386

[17] Pearson, C., \& Mitroff, I. (1993). From Crisis Prone to Crisis Prepared: A Framework for Crisis Management. The Executive, 7(1), 48-59.

[18] Piercy, N. F., Cravens, D. W., \& Lane, N. (2010). Marketing out of the recession: recovery is coming, but things will never be the same again. The Marketing Review, 10(1), 3-23. https://doi.org/10.1362/146934710X488915

[19] Quelch, J. (2008). Marketing your way through a recession. The Financial Times of London. February 19, reprint in HBS Working Knowledge

[20] Quelch, J. A. \& Jocz, K. E. (2009). How to market in a downturn. Harvard Business Review, 87(4), 52-62. 
[21] Seeger, M. W., Sellnow, T. L., \& Ulmer, R. R. (2003). Communication and organizational crisis. Greenwood Publishing Group: Westport.

[22] World Bank (2020), The Impact of COVID-19 on Formal Firms: Evidence from Albania

https://openknowledge.worldbank.org/bitstream/handle/10986/34392/T he-Impact-of-COVID-19-on-Formal-Firms-Evidence-from-

Albania.pdf?sequence $=1$ \&isAllowed $=y$

[23] Weick, K., \& Sutcliffe, K. (2007). Managing the unexpected resilient performance in an age of uncertainty. (2nd ed.). San Francisco: Jossey-Bass.

[24] Williams, T. A., Gruber, D. A., Sutcliffe, K., M., Shepherd, D. A., \& Zhao, W. Y. (2017). Organizational Response to Adversity: Fusing Crisis Management and Resilience Research Streams. Academy of Management Annals, 11(2), 57-69. https://doi.org/10.5465/annals.2015.0134 